\title{
4. KONFERENCA IZOBRAŽEVALNI MANAGEMENT 2004
}

\section{8. in 19. novembra 2004 v Portorožu}

$\mathrm{P}$ od okriljem podjetja GV Izobraževanje in revije HRM je novembra v Portorožu potekalo četrto srečanje izobraževalnih menedžerjev, predavateljev, trenerjev in drugih svetovalnih in andragoških delavcev.

Moderatorka konference je bila Živa Gorup Reichmann, izkušena $\vee$ razvoju pristopov in modelov upravljanja znanja zaposlenih: zemljevid znanja, merjenje učinkovitosti izobraževanja, ciljno usmerjeno izobraževanje. Konferenco si bomo zapómnili po šestih plenarnih referatih in šestih izbirnih sekcijah, v katerih smo spoznavali primere dobrih praks, iz katerih se velja učiti in jim slediti.

$\mathrm{Z}$ makroekonomskim pogledom na vlogo znanja je konferenco odprla dr. Alenka Kajzer z Urada RS za makroekonomske analize. Dejala je, da se bodo zaradi gospodarskega razvoja, ki povprašuje predvsem po izobraženi delovni sili, strukturna neskladja na trgu dela samo še povečevala in jih bo potrebno reševati predvsem $z$ vseživljenjskim izobraževanjem, pri čemer bo treba spodbujati povpraševanje in vlaganje $\mathrm{v}$ izobraŽevanje ter usposabljanje pri posameznikih in delodajalcih (s subvencioniranjem in sofinanciranjem izobraževanja ter davčnimi olajšavami) in povečanjem fleksibilnosti trga dela. $\mathrm{Z}$ odmevnim prispevkom je nadaljevala dr. Sabina Jelenc Krašovec s Filozofske fakultete $v$ Ljubljani, ki je bila kritična do uporabe terminov vseživljenjsko učenje in izobraževanje. Pojem vseživljenjsko učenje naj bi dobil poleg doslej poudarjene ver- tikalne razsežnosti (life-long - skozi vse življenje, v vseh obdobjih življenja) tudi horizontalno (life-wide - vseobsegajoče, v vsej širini življenja). Opozorila je, da bi se morali zaposlovalci in drugi gospodarstveniki vprašati, kako zagotoviti in podpirati izobraževanje, ki bi pripomoglo k uskladitvi materialnega napredka s spoštovanjem človekovega življenja in tako ustvariti razmere za bolj celostno rast in razvoj vsega prebivalstva.

O viziji izobraževalnega projekta $v$ okviru vizije podjetja je spregovorila Mirjam Dominko iz Candorja. Posebej je poudarila, da mora biti sleherni izobraževalni projekt povezan s splošno vizijo podjetja, zato je $\mathrm{k}$ oblikovanju vizije izobraževalnega projekta potrebno povabiti tim sodelavcev, $\mathrm{ki}$ se ukvarjajo z zaposlenimi v podjetju, vse, ki jim je projekt namenjen, vodstvo podjetja in izvajalce izobraževanja.

Dr. Adriana Rejc z Ekonomske fakultete v Ljubljani je nadaljevala z mikroizobraževalno temo o metodah za merjenje učinkovitosti izobraževanja. Predlagala je merjenje na treh ravneh: kako izvajamo izobraževanje, kakšni so vplivi izobraževanja na vedenje zaposlenih in kakšen je vpliv izobraževanja na finančno uspešnost podjetja. Prikazala je postopek izračuna finančnih koristi iz izobraževanja, izračun celotnih stroškov izobraževalnega projekta in izračun donosnosti izobraževalnega projekta.

Zanimiva je bila tudi delavnica, ki so jo 
pripravili člani Društva moderatorjev Slovenije. $Z$ animiranjem celotne skupine udeležencev konference so prikazali, kakšna je lahko vloga moderatorja $\mathrm{v}$ podjetju/organizaciji. Skupaj z udeleženci so odigrali, kako lahko podjetje izkoristi prednosti moderatorja pri reševanju določenega problema. Prednosti oziroma ključne lastnosti moderatorja so namreč njegova vsebinska nevtralnost, izvedenost za proces, večanje produktivnosti in ustvarjalnosti ter da uravnoveša sodelovanje in je odprt za spremembe.

Naj omenimo še dva plenarna nastopa. Gregor Levič iz Edupoola je predstavil rezultate raziskave o stanju izobraževalne funkcije v 293 slovenskih podjetjih, Metka Tržan z Zavoda za varstvo pri delu pa je predstavila, kako z izobraževanjem promovirati zdravje $v$ podjetjih in drugih organizacijah. Opozorila je, da promocije zdravja nikakor ne smemo obravnavati kot stroške, ampak kot pomembno naložbo, s katero bo zagotovljena boljša prihodnost in višja raven kakovosti življenja zaposlenih prebivalcev.

Udeleženci konference so labko sodelovali tudi v šestih izbirnih sekcijah. Zvonko Belič iz Save je prikazal metodo 20 ključev oziroma kako obvladovati kompetence zaposlenih z matriko veščin, Gordana Jeglič iz Intereurope in Helena Urbančič iz IBM Slovenija sta predstavili Intereuropino šolo vodenja po programu UBM Management Development, kako evalvirati e-izobraževanje, pa smo izvedeli in o tem tudi razpravljali v sekciji, ki sta jo vodili Marija Stanič in Klavdija Macedoni iz Interesa. V obliki delavnice smo $z$ Robertom Kržišnikom iz Humusa spoznavali, kaj naredi res dobro delavnico; katere so kvalitete dobrega voditelja, kaj maksimalno pritegne skupino, kakš̃no je stimulatiyno okolje in kaj naredi sdober dramaturški lok . Mag. Darja Zorko Mencin iz Službe vlade RS za strukturno politiko in regionalni razvoj nas je napotila, kako do izobraževalnega »budžeta« iz evropskih strukturnih skladov, mag. Daniela Brečko pa nam je zaupala, na kakšen način se izobražujejo menedžerji. Ker nimajo časa za izobraževanje, je njihova najaktualnejša oblika individualno izobraževanje. Veliko menedžerjev in vodilnih kadrov že izvaja individualne učne programe, ki so mešanica različnih področij, izobražujejo pa se z inštruktorjem.

$\mathrm{Na}$ konferenci smo spoznali in čestitali letošnjim dobitnikom priznanj TOP 10, podjetjem, ki največ vlagajo v izobraževanje in usposabljanje zaposlenih. Priznanja so prejeli: Smart com d. o. o, Krka d. d., SRC.si d.o.o., Lek d. d., Cetis d. d., TBP d. d., Premogovnik Velenje d. d,, Banka Koper d. d. in Merkur d. d.

Ključna misel letošnje konference Izobraževalni management je, da izobraževanje v podjetjih in drugih organizacijah ne more biti odgovornost in naloga enega strokovnjaka, pač pa je to odgovornost tima, vseh zaposlenih, predvsem pa vodilnih menedžerjev, Zato naj kot spodbuda pri razširjanju tega prepričanja velja povabilo, da se nam na naslednji konferenci poleg izobraževalcev in kadrovikov pridružijo tudi predstavniki najvišjega vodstva.
Melanija Končina GV Izobraževanje 